\title{
Effect of Different Pre-sowing Seed Treatments for Improving Growth, Yield and Yield Attributes in Foxtail Millet [Setaria italica (L.) P. Beauv]
}

\author{
Rajaka Karthik Kumar*, Arun kumar Chaurasia, Nuthalapati karthik and M. Kavitha
}

Department of Genetics and Plant Breeding, Naini Agricultural Institute, Sam Higginbottom

University of Agriculture, Technology and Sciences, Prayagraj, 211007, Uttar Pradesh, India

*Corresponding author

\section{A B S T R A C T}

Keywords

Foxtail millet, $\mathrm{CaCl} 2, \mathrm{KNO} 3$, GA3, IAA, CuSo4, ZnSo4, Quality parameters

Article Info

\section{Accepted:}

15 January 2021

Available Online:

10 February 2021
The experiment was conducted in post graduate Seed Testing Laboratory and field, Department of Genetics and Plant Breeding, Sam Higginbottom University of Agriculture, Technology and Sciences, Prayagraj (U.P.) during Kharif season 20192020, in order to standardize the suitable fortification seed treatment of Foxtail millet Pre-sowing seed treatments with control (Unhardened) were evaluated by screening 12 hour viz., $\mathrm{T}_{0}-\mathrm{Control}, \mathrm{T}_{1}-\mathrm{CaCl}_{2} @ 1 \%, \mathrm{~T}_{2}-\mathrm{CaCl}_{2} @ 3 \%, \mathrm{~T}_{3}-\mathrm{KNO}_{3} @ 1 \%, \mathrm{~T}_{4}-$ $\mathrm{KNO}_{3} @ 3 \%, \mathrm{~T}_{5}-\mathrm{GA}_{3} @ 50 \mathrm{ppm}, \mathrm{T}_{6}-\mathrm{GA}_{3} @ 100 \mathrm{ppm}, \mathrm{T}_{7}-\mathrm{IAA} @ 50 \mathrm{ppm}, \mathrm{T}_{8}-$ IAA@100 ppm, T9 $-\mathrm{CuSo}_{4} @ 50$ ppm, $\mathrm{T}_{10}-\mathrm{CuSo}_{4} @ 100$ ppm, $\mathrm{T}_{11}-\mathrm{ZnSo}_{4} @ 50$ ppm and $\mathrm{T}_{12}-\mathrm{ZnSo}_{4} @ 100$ ppm. It was found that all the fortified seed treatments showed significance difference with the control and in laboratory condition highest germination per cent, seedling length, seedling fresh weight, seedling dry weight, vigour indices were observed for $\mathrm{T}_{5}-\mathrm{GA}_{3}(50 \mathrm{ppm})$. In field lowest taken days to $50 \%$ flowering by $\mathrm{T}_{7}$ - IAA @ $50 \mathrm{ppm}$ and number of leaves per plant, number of seeds per plant, seed yield per plot, biological yield, harvest index were observed for $\mathrm{T}_{5^{-}} \mathrm{GA}_{3} @$ 50 ppm. Observed highest germination, growth and yielding attributes in $\mathrm{GA}_{3} @ 50$ ppm. Pre-sowing seed treatment with $\mathrm{GA}_{3}$ enhance germinability, vigour and seedling character, its simplicity and no requirement for expensive equipment and chemical could be used as a simple method for overcoming related to a poor germination and seedling establishment.

\section{Introduction}

Millets - The Miracle Grains are a group of highly variable small-seeded grasses, widely grown around the world as cereal crops or grains for fodder and human food. Millets are important crops in the semiarid tropics of Asia and Africa (especially in India, Mali, Nigeria, and Niger), with $97 \%$ of millet production in developing countries. Small millets are a group of grassy plants with short slender culm and small grains possessing remarkable ability to survive under adverse conditions like limited rainfall, poor soil fertility and land 
terrain making them an attractive crop for marginal farming environments (Saleh et al., 2013). The crop is favored due to its productivity and short growing season under dry, high-temperature conditions.

The term millet is employed for several related genera, some used to produce grain, or forage or both. Millets are cereal species growing in an equally broad range of environments. The most widely cultivated millets are finger millet (Eleusine coracona), foxtail millet (Setaria itallica), pearl millet (Pennisetum typhoideum), proso millet (Panicum miliaceum), barnyard millet (Echinochloa colona) etc. Millets are considered the least important of cereals, with annual production less than $2 \%$ of the world's grain.

However, they are of great local importance as staples and as reserve crops in marginal areas. Millet contains an average of $10-12 \%$ protein. While its protein is superior to that of wheat or corn in terms of content of essential amino acids, and it contains less than half the amount of the essential amino acid lysine that is found in high quality protein sources such as meat. Millet lacks gluten, the wheat protein that makes dough prepared from wheat flour elastic; hence millet flour is not suitable for leavened breads. Millet flour is used in making flat cakes and breads (Robert Ronzio2004).

Foxtail millet (Setaria italica (L.) P. Beauv.) (Synonym Panicum italicum L.), family Paniceae/Poaceae, subfamily Panicoideae, tribe Chloridoideae, is diploid with nine chromosomes $2 \mathrm{n}=18$. It is, however, closely related to tetraploid and polyploid species of Setaria (Benabdelmouna et al., 2001). It is an annual grass grown for human food. It is the second-most widely planted species of millet, and the most important in East Asia. It is the second-most cultivated millet (also known as
"Korralu" in Andhra Pradesh and "Thinai" in Tamil Nadu and "Kang" or "Rala" in Maharashtra, "Kakum" in Hindi) in India (Lata et al., 2011).

Foxtail millet is a member of the Paniceae tribe (subfamily Panicoideae of the Poaceae) and came from green millet domestication in northern China about for 8000 years ago (Barton et al., 2009). Foxtail millet and its ancestor green foxtail (Setaria viridis) became more attractive to plant scientists as an alternative model plant because of several distinct characteristics, such as their short stature, rapid life cycle, sufficient seed production per plant, self-compatibility, true diploid nature, and small genome size (515 and $395 \mathrm{Mb}$, respectively) (Doust et al., 2009; Huang et al., 2016; Pant et al., 2016).

More importantly, foxtail millet and green foxtail are typical $\mathrm{C}_{4}$ plants, similar to maize, sorghum and sugarcane, and therefore can be a valuable model plant for studies of $\mathrm{C}_{4}$ photosynthesis (Pant et al., 2016; Huang et al., 2017; Yang et al., 2018). Cereal proteins including millets are limited in lysine and tryptophan content and vary with cultivar.

However, most cereals contain the essential amino acids as well as vitamins and minerals (Devi et al., 2011; FAO, 2009). Foxtail millet is extensively cultivated in the developing countries in semiarid and arid regions of Africa, Americas, Asia (Lata et al., 2013) because of its health benefits (a particular balance of nutrients, e.g., starch, protein, dietary fibers, fat, vitamins, and low-glycemic and hypolipidemic effects), good yield with minimal agricultural inputs, and adaptation to different biotic and abiotic stresses such as salinity (Lata et al., 2011), drought (Feldman et al., 2017), and fungal diseases (Xu et al., 2011). A healthy and environmentally friendly small crop of foxtail is an increasingly attractive alternative for crop production. 
Foxtail millet contains a pertinent number of nutritional components, especially starch, protein, vitamins, and minerals. Nutritional constituents of foxtail millet per 100 g. protein (12.3 g.), carbohydrate (60.9 g.), fat (4.3 g.), crude fiber $(8.0$ g.), mineral matter (3.3 g.), energy (351 kcal) (Muthamilarasan et al., 2016). Morphologically, foxtail millet grains have layers of husk and bran, similar to other millet grains. The husk forms $13.5 \%$ $(\mathrm{w} / \mathrm{w})$ of the grain, and the bran and the germ only constitute $1.5-2 \%(\mathrm{w} / \mathrm{w})$ (Dharmaraj et al., 2016). It has a short generation time of 58 weeks from planting to flowering, 8-15 weeks from planting to seed maturity, and can produce hundreds of seeds per inflorescence (Doust et al., 2009).

The use of millets not only provides farmers with a market for their products but also saves foreign exchange, which would otherwise be required to import cereals. Particularly in the developed countries, there is a growing demand for gluten-free foods and beverages from people with celiac disease and other intolerances to wheat that cannot eat products from wheat, barley, or rye.

Seed is a basic input in agriculture in which 25 $\%$ yield increase can be achieved by quality seeds. Quality seed is the key for successful agriculture, which demands each and every seed should be readily germinable and produce a vigorous seedling ensuring higher yield. To provide higher quality seeds, many researchers have developed new technologies called "Seed Enhancement Techniques" (Talebian et al., 2008).

Seed fortification is a physiological method of seed invigoration that aids in improving the initial stamina of the seed that helps in improving the initial field establishment and that of the final yield. It is the impregnation of the needy substance into the seed through the imbibition's phase enriching the endogenous level of needy bioactive substances. In seed fortification, seeds are partially hydrated to allow metabolic events to occur without actual germination, and then re-dried (near to their original weight) to permit routine handling. Such seeds germinate faster than non-fortified seeds. Hence, the utility of inorganic nutrients as seed fortification agents were evaluated for improving the germination and field emergence of maize, paddy and ragi (Goto $e t$ al., 1999).

Seed treated with halogens is one of the very important seed treatment technique apply with salt solution like as $\mathrm{KCl}, \mathrm{CaCl}_{2}, \mathrm{NaCl}, \mathrm{CaCl}_{2}$ and $\mathrm{KNO}_{3}$ solution concentration. Seeds were soaked in salt solution, after dried and at room temperature and subjected to germination test, done at $25^{\circ} \mathrm{C}$ for 24 hrs. Germination percentage of primed seeds was greater than that of un- primed seeds (Bajehbaj, 2010).

The seed bio-priming is an effective seed treatment to increase the rate, rapid emergence, uniformity of emergence and crop establishment in most of the crops (Rawat $e t$ al., 2011). It integrates the biological and physiological aspects of enhancing growth, disease control and increase in yield, which involves coating the seed with biological agents and incubating the seed under warm, moist conditions.

\section{Materials and Methods}

The experiment was carried out to study the Effect of different pre-sowing seed treatments for improving growth, yield and seed quality parameters in Foxtail millet (Setaria italica (L.) P. Beauv.).

The experiment was carried out at the Laboratory and field of Seed Science and Technology at the Department of Genetics and Plant Breeding, SHUATS, Prayagraj UP. The seed treatments are $\mathrm{T}^{0-}$ control, $\mathrm{T}^{1}-$ Calcium 
chloride $1 \%, \mathrm{~T}^{2}$-Calcium chloride 3\%, $\mathrm{T}^{3}$ Potassium nitrtate $1 \%, \mathrm{~T}^{4}$ - Potassium nitrate $3 \%, \quad \mathrm{~T}^{5}-$ Gibberellic acid $50_{\mathrm{ppm}}, \mathrm{T}^{6}-$ Gibberellic acid $100_{\mathrm{ppm}}, \mathrm{T}^{7}$-Indole acetic acid $50_{\mathrm{ppm}}, \mathrm{T}^{8}$ - Indole acetic acid $100_{\mathrm{ppm}}, \mathrm{T}^{9}-$ Copper sulphate $50 \mathrm{ppm}, \mathrm{T}^{10}$ - Copper sulphate $100_{\mathrm{ppm}}, \mathrm{T}^{11}-$ Zinc sulphate $50_{\mathrm{ppm}}, \mathrm{T}^{12}-$ Zinc sulphate $100_{\mathrm{ppm}}$.

To carryout the experiment the seeds were sown in thirteen plots each in three replications with spacing of $22.5 \times 10 \mathrm{~cm}$ using line sowing methods following Randomize Block Design.

Data collected of field emergence, it was expressed in percentage, Days to 50\% flowering, Plant height of 60 and 90 days, it was expressed in centimeter, number of fingers per panicle, seed yield per plot expressed in grams, seed yield per plant expressed in grams, Biological yield and Harvesting index.

The data recorded from field were analysed statistically following the method of analysis of variance(Fisher, 1948).

\section{Preparation of solution}

For the preparation of salt solution, Ten gram $\mathrm{CaCl}_{2}$ was taken in a beaker. The chemical were added in $1000 \mathrm{ml}$. of distilled water with constant stirring. The volume of solution will finally constitute to one litter, and then it became $1 \%$ stock solution of $\mathrm{CaCl}_{2}$ chemical and so on.

The flasks containing chemicals were covered with muslin cloth to avoid any contamination. For the preparation of solution of the Plant growth regulators, to prepare $50 \mathrm{ppm}$ solution of $\mathrm{GA}_{3}, 50 \mathrm{mg}$ Gibberellic Acid were taken in a beaker and the chemical were added in 1000 $\mathrm{ml}$. of distilled water with constant stirring. The volume of solution will finally constitute to one litter, and then it became $50 \mathrm{ppm}$ stock solution of Gibberellic Acid chemical and so on. The flasks containing chemicals were covered with muslin cloth to avoid any contamination. For the preparation of solution of the Sulphate ions, to prepare $100 \mathrm{ppm}$ solution of $\mathrm{ZnSO}_{4}, 100 \mathrm{mg}$ Zinc sulphate were taken in a beaker and the chemical were added in $1000 \mathrm{ml}$. of distilled water with constant stirring. The volume of solution will finally constitute to one litter, and then it became 100 ppm stock solution of Zinc sulphate chemical and so on. The flasks containing chemicals were covered with muslin cloth to avoid any contamination.

\section{Seeds soaking in the solution}

After preparation of solution of $\mathrm{CaCl}_{2}, \mathrm{KNO}_{3}$, $\mathrm{GA}_{3}$, IAA, $\mathrm{CuSO}_{4}$ and $\mathrm{ZnSo}_{4}$, foxtail millet seeds were soaked in required solution for 12 hours at $25^{\circ} \mathrm{C}$ temperature. Untreated seed is called as control. After 12 hours of soaking the solution were drained out from the beaker and dried 24 hours at $25^{\circ} \mathrm{C}$ temperature to original weight and then placed for germination in laboratory under controlled condition.

\section{Results and Discussion}

The field experiment was conducted to study the Effect of different pre-sowing seed treatments for improving growth, yield and yield attributes in Foxtail millet [Setaria italica (L.) P. Beauv.].

The mean performance of field emergence percent ranged from $77.67 \%$ to $87.33 \%$ with mean value of $82.38 \%$. Significantly highest field emergence percentage $(87.33 \%)$ was reported in the pre-sowing treatment with $\mathrm{T}_{5}$ Gibberellic acid $\left(\mathrm{GA}_{3}\right)$ @ $50 \mathrm{ppm}$ it was followed by $\mathrm{T}_{7}-(86.00 \%)$ with application of Indole 3 Acetic Acid (IAA) @ 50 ppm and $\mathrm{T}_{3}$ - (85.00\%) with application of Potassium 
nitrate $\left(\mathrm{KNO}_{3}\right) @ 1 \%$. Minimum field emergence percentage was recorded by $\mathrm{T}_{0^{-}}$ (77.67\%) with control. Days to $50 \%$ flowering ranged from 47 to 56 with mean value of 51.08. Significantly taken lowest days to $50 \%$ flowering (47.00) was reported in pre-sowing treatment with $\mathrm{T}_{7}$ - Indole 3 Acetic Acid (IAA)@ 50 ppm it was followed by $\mathrm{T}_{5}$ (48.00) with application of Gibberellic acid $\left(\mathrm{GA}_{3}\right) @ 50 \mathrm{ppm}$ and $\mathrm{T}_{4}-(49.00)$ with application of Potassium nitrate $\left(\mathrm{KNO}_{3}\right)$ @ $3 \%$. Maximum days to $50 \%$ flowering was recorded by $\mathrm{T}_{0}$ - (56.00) with control

Plant height at 45 DAS ranged from $56.57 \mathrm{~cm}$ to $66.13 \mathrm{~cm}$ with mean value of $62.24 \mathrm{~cm}$. Plant height at 45 DAS found to be highest $(66.13 \mathrm{~cm})$ in pre-sowing treatment withT $_{5}$ Gibberellic acid $\left(\mathrm{GA}_{3}\right) @ 50 \mathrm{ppm}$ it was followed by $\mathrm{T}_{7}-(65.60 \mathrm{~cm})$ with application of Indole 3 Acetic Acid (IAA) @ 50 ppm and $\mathrm{T}_{4}$ - $(64.70 \mathrm{~cm})$ with application of Potassium nitrate $\left(\mathrm{KNO}_{3}\right) @ 3 \%$. Minimum plant height at 45 DAS was recorded by $\mathrm{T}_{0}-(56.57 \mathrm{~cm})$ with control. Plant height at 90 DAS ranged from $78.80 \mathrm{~cm}$ to $90.50 \mathrm{~cm}$ with mean value of $84.78 \mathrm{~cm}$. Plant height at 90 DAS found to be highest $(90.50 \mathrm{~cm})$ in pre-sowing treatment with $\mathrm{T}_{7}$ - Indole 3 Acetic Acid (IAA) @ 50 ppm it was followed by $\mathrm{T}_{5}-(89.10 \mathrm{~cm})$ with application of Gibberellic acid $\left(\mathrm{GA}_{3}\right) @ 50$ ppm and $\mathrm{T}_{3}-(87.63 \mathrm{~cm})$ with application of Potassium nitrate $\left(\mathrm{KNO}_{3}\right) @ 1 \%$. Minimum plant height at $90 \mathrm{DAS}$ was recorded by $\mathrm{T}_{0}$ $(78.80 \mathrm{~cm})$ with control.

Number of Leaves per plant ranged from 5.33 to 7.80 with mean value of 6.50 . Significantly highest number of leaves per plant (7.80) was reported in the pre-sowing treatment with $\mathrm{T}_{5}$ Gibberellic acid $\left(\mathrm{GA}_{3}\right) @ 50$ ppm it was followed by $\mathrm{T}_{7}$ - (7.40) with application of Indole 3 Acetic Acid (IAA) @ 50 ppm and $\mathrm{T}_{3}$ - (7.13) with application of Potassium nitrate $\left(\mathrm{KNO}_{3}\right) @ 1 \%$. Minimum number of leaves per plant was recorded by $\mathrm{T}_{0^{-}}$(5.33) with control. Number of seeds per plant ranged from 663.67 to 1210.00 with mean value of 933.38. Significantly highest number of seeds per plant (1210.00) was reported in the presowing treatment with $\mathrm{T}_{5}$ - Gibberellic acid $\left(\mathrm{GA}_{3}\right) @ 50 \mathrm{ppm}$ it was followed by $\mathrm{T}_{7}$ (1180.00) with application of Indole 3 Acetic Acid (IAA) @ 50 ppm and $\mathrm{T}_{4}$ - (1130.00)with application of Potassium nitrate $\left(\mathrm{KNO}_{3}\right)$ @ $3 \%$. Minimum number of seeds per plant was recorded by $\mathrm{T}_{0}$ - (663.67) with control.

Seed yield per plant ranged from $1.45 \mathrm{gm}$ to $3.82 \mathrm{gm}$ with mean value of $2.58 \mathrm{gm}$. Significantly highest seed yield per plant (3.82 gm) was reported in the pre-sowing treatment with $\mathrm{T}_{5}$ - Gibberellic acid $\left(\mathrm{GA}_{3}\right) @ 50 \mathrm{ppm}$ it was followed by $\mathrm{T}_{7}-(3.63 \mathrm{gm})$ with application of Indole 3 Acetic Acid (IAA) @ $50 \mathrm{ppm}$ and $\mathrm{T}_{4^{-}}(3.37 \mathrm{gm})$ with application of Potassium nitrate $\left(\mathrm{KNO}_{3}\right) @ 3 \%$. Minimum seed yield per plant was recorded by $\mathrm{T}_{0^{-}}(1.45$ gm) with control. Seed yield per plot ranged from $67.11 \mathrm{gm}$ to $174.46 \mathrm{gm}$ with mean value of $115.15 \mathrm{gm}$.

Significantly highest seed yield per plot (174.46 gm) was reported in the pre-sowing treatment with $\mathrm{T}_{5}$ - Gibberellic acid $\left(\mathrm{GA}_{3}\right) @$ $50 \mathrm{ppm}$ it was followed by $\mathrm{T}_{7}-(160.92 \mathrm{gm})$ with application of Indole 3 Acetic Acid (IAA) @ 50 ppm and $\mathrm{T}_{4}$ - (153.71 gm) with application of Potassium nitrate $\left(\mathrm{KNO}_{3}\right)$ @ $3 \%$. Minimum seed yield per plot was recorded by $\mathrm{T}_{0^{-}}(67.11 \mathrm{gm})$ with control. Biological yield ranged from $310.02 \mathrm{gm}$ to $531.36 \mathrm{gm}$ with mean value of $411.93 \mathrm{gm}$. Significantly highest biological yield (531.36 gm) was reported in the pre-sowing treatment with $\mathrm{T}_{5}-$ Gibberellic acid $\left(\mathrm{GA}_{3}\right) @ 50 \mathrm{ppm}$ it was followed by $\mathrm{T}_{7}-(503.60 \mathrm{gm})$ with application of Indole 3 Acetic Acid (IAA) @ $50 \mathrm{ppm}$ and $\mathrm{T}_{4}-(493.73 \mathrm{gm})$ with application of Potassium nitrate $\left(\mathrm{KNO}_{3}\right)$ @ 3\%. Minimum biological yield was recorded by $\mathrm{T}_{0}$ - (310.02 gm) with control (Table 1). 
Table.1 Mean performance of foxtail millet for ten growth and yield characters.

\begin{tabular}{|c|c|c|c|c|c|c|c|c|c|c|c|}
\hline S.NO. & Treatments & $\begin{array}{c}\text { Field } \\
\text { emergence } \\
\text { percentage }\end{array}$ & $\begin{array}{c}\text { Days to } \\
50 \% \\
\text { flowering }\end{array}$ & $\begin{array}{l}\text { Plant } \\
\text { height } \\
\text { at } 45 \\
\text { DAS } \\
\text { (cm) }\end{array}$ & $\begin{array}{c}\text { Plant } \\
\text { height } \\
\text { at } 90 \\
\text { DAS } \\
\text { (cm) }\end{array}$ & $\begin{array}{c}\text { Number } \\
\text { of leaves } \\
\text { per } \\
\text { plant }\end{array}$ & $\begin{array}{c}\text { Number } \\
\text { of seeds } \\
\text { per } \\
\text { plant }\end{array}$ & $\begin{array}{l}\text { Seed } \\
\text { yield } \\
\text { per } \\
\text { plant } \\
\text { (g) }\end{array}$ & $\begin{array}{l}\text { Seed } \\
\text { yield } \\
\text { per } \\
\text { plot } \\
\text { (g) }\end{array}$ & $\begin{array}{l}\text { Biological } \\
\text { yield (g) }\end{array}$ & $\begin{array}{c}\text { Harvest } \\
\text { index } \\
(\%)\end{array}$ \\
\hline 1 & $\mathbf{T}_{\mathbf{0}}$ & 77.67 & 53 & 56.57 & 78.80 & 5.33 & 663.66 & 1.45 & 67.11 & 310.02 & 21.68 \\
\hline 2 & $\mathbf{T}_{1}$ & 83.00 & 50 & 63.03 & 86.20 & 6.60 & 924.00 & 2.69 & 114.66 & 401.22 & 28.60 \\
\hline 3 & $\mathbf{T}_{2}$ & 81.67 & 51 & 62.03 & 83.80 & 6.27 & 873.67 & 2.43 & 105.13 & 412.09 & 25.54 \\
\hline 4 & $\mathbf{T}_{3}$ & 85.00 & 49 & 63.90 & 87.63 & 7.13 & 1030.67 & 3.14 & 143.26 & 466.25 & 30.72 \\
\hline 5 & $\mathbf{T}_{4}$ & 83.67 & 49 & 64.70 & 86.90 & 6.93 & 1130.00 & 3.37 & 153.71 & 493.73 & 31.12 \\
\hline 6 & $\mathbf{T}_{5}$ & 87.33 & 48 & 66.13 & 89.10 & 7.80 & 1210.00 & 3.82 & 174.46 & 531.36 & 32.83 \\
\hline 7 & $\mathbf{T}_{6}$ & 84.00 & 50 & 63.50 & 87.17 & 6.80 & 1020.00 & 2.73 & 118.86 & 394.44 & 30.14 \\
\hline 8 & $\mathbf{T}_{7}$ & 86.00 & 47 & 65.60 & 90.50 & 7.40 & 1180.00 & 3.63 & 160.92 & 503.60 & 32.09 \\
\hline 9 & $\mathbf{T}_{8}$ & 79.33 & 55 & 58.87 & 80.30 & 5.73 & 762.33 & 1.80 & 79.64 & 353.83 & 22.55 \\
\hline 10 & $\mathbf{T}_{9}$ & 80.33 & 52 & 61.70 & 83.10 & 6.13 & 858.67 & 2.18 & 98.95 & 376.40 & 26.33 \\
\hline 11 & T10 & 80.00 & 54 & 59.80 & 80.70 & 5.87 & 768.67 & 1.87 & 82.96 & 348.89 & 23.81 \\
\hline 12 & T11 & 82.00 & 50 & 62.50 & 85.57 & 6.47 & 903.67 & 2.47 & 107.78 & 399.41 & 27.02 \\
\hline 13 & T12 & 81.00 & 56 & 60.73 & 82.40 & 6.00 & 808.67 & 2.00 & 89.56 & 363.88 & 24.63 \\
\hline \multicolumn{2}{|c|}{ Grand Mean } & 82.38 & 51.08 & 62.24 & 84.78 & 6.50 & 933.38 & 2.58 & 115.15 & 411.93 & 27.47 \\
\hline \multicolumn{2}{|c|}{ C.D. $(5 \%)$} & 3.15 & 1.92 & 1.64 & 1.66 & 0.24 & 30.70 & 0.15 & 11.94 & 51.36 & 1.71 \\
\hline \multicolumn{2}{|r|}{ SE(m) } & 0.08 & 0.66 & 0.56 & 0.57 & 0.08 & 10.52 & 0.05 & 4.09 & 17.59 & 0.58 \\
\hline \multicolumn{2}{|r|}{$\mathrm{SE}(d)$} & 1.52 & 0.93 & 0.79 & 0.81 & 0.12 & 14.87 & 0.07 & 5.79 & 24.88 & 0.83 \\
\hline \multicolumn{2}{|r|}{ C.V. } & 2.27 & 2.23 & 1.56 & 1.16 & 2.24 & 1.95 & 3.48 & 6.15 & 7.40 & 3.69 \\
\hline \multirow[b]{2}{*}{ Range } & Max & 87.33 & 56 & 66.13 & 90.50 & 7.80 & 1210.00 & 3.63 & 174.46 & 531.36 & 32.83 \\
\hline & Min & 77.67 & 47 & 56.57 & 78.80 & 5.33 & 663.66 & 1.45 & 67.11 & 310.02 & 21.68 \\
\hline
\end{tabular}


Harvest index ranged from $21.68 \%$ to $32.83 \%$ with mean value of $27.47 \%$. Significantly highest harvest index $(32.83 \%)$ was reported in pre-sowing treatment with $\mathrm{T}_{5}$ - Gibberellic acid $\left(\mathrm{GA}_{3}\right) @ 50$ ppm it was followed by $\mathrm{T}_{7}$ (32.09\%) with application of Indole 3 Acetic Acid (IAA) @ 50 ppm and $\mathrm{T}_{4}-(31.12 \%)$ with application of Potassium nitrate $\left(\mathrm{KNO}_{3}\right)$ @ $3 \%$. Minimum Harvest index was recorded by $\mathrm{T}_{0}-(21.68 \%)$ with control

Pre-sowing is a physiological method of seed invigoration that aids in improving the initial stamina of the seed that helps in improving the initial field establishment and that of the final yield. It is the impregnation of the needy substance into the seed through the imbibition's phase enriching the endogenous level of needy bioactive substances.

In pre-sowing treatment, seeds are partially hydrated to allow metabolic events to occur without actual germination, and then re-dried (near to their original weight) to permit routine handling. Such seeds germinate faster than non-pre sowed treatment seeds. Hence, the utility of inorganic nutrients as pre sowing agents were evaluated for improving the germination and field emergence.

On the basis of results obtained from the present experiment following conclusions are drawn.

Pre-sowing seed treatment increases the germinability and vigour of foxtail millet seeds, significantly in field condition. Presowing treatment with Gibberellic acid @ 50 ppm followed by Indole 3 Acetic Acid @ 50 ppm, Pre-sowing treatment with $\mathrm{GA}_{3}$ and IAA showed maximum increase in germinability and vigour of foxtail millet seeds and found to be lowest in control seeds. These conclusions are based on the results of six months investigation and therefore further investigation is needed to arrive at valid recommendations. The Pre-sowing seed treatment with $\mathrm{GA}_{3}$ are eco -friendly, enhancing planting value and economic in use.

\section{References}

Abdul Baki, A.A, and Anderson J.D. (1973).Vigor determination in soybean seed by multiple criteria. Crop. Science. 13: 630-633.

Aboutalebian, M.A., Ekbatani, G.Z. and Sepehri, A. (2012). Effects of on-farm seed priming with zinc sulfate and urea solutions on emergence properties, yield and yield components of three rainfed wheat cultivars. Annals of Bio. Res., 3(10): 4790-4796.

Aladjadjiyan, A. (2012). -Physical factors for plant growth stimulation improve food quality,\| in Food Production Approaches, Challenges and Tasks, ed. A. Aladjadjiyan (Rijeka: InTech), 145168.

Amin, R., Khan, A.Z., Muhammad, A., Khalil, S.K., Gul, H., Daraz, G., Akbar, H. and Ghoneim, A.M. (2016).Influence of seed hardening techniques on vigour, growth and yield of wheat under drought conditions. Journal of Agricultural Studies., 4 (3): 121-131.

Anburani, A. and Shakila, A. (2010).Influence of seed treatment on the enhancement of germination and seedling vigour of papaya. Acta Horticulturae., 851: 295298.

Anitha, K.G. (2010). Enhancing seed germination of mono and dicotyledons through IAA production of PPFM.Trends Soils Sci. Plant Nutr.J., 1: 14- 18.

Arif, M., Waqas, M., Nawab, K. and Shahid, M. (2007). Effect of seed priming in $\mathrm{Zn}$ solutions on chickpea and wheat. African Crop Science Journal., 8: 237240.

Ashraf, M. and Foolad, M.R. (2005). Pre- 
sowing seed treatment: a shot-gun approach to improve germination growth and crop yield under saline and non-saline conditions. Advances in Agronomy., 88: 223-271.

Atia, A., Debez, A., Rabhi, M., Athar, H.U.R. and Abdelly, C. (2006). Alleviation of salt- induced seed dormancy in the perennial halophyte Crithmum maritimum. Pak. J. Bot., 38(5): 13671372.

Bailly, C., Benamar, A., Corbineau, F. and Come, D. (2000).Antioxidant systems in sunflower (Helianthus annuus L.) seeds as affected by priming.Seed Science Research., 10: 35-42.

Bajehbaj, A.A. (2010). The effects of $\mathrm{NaCl}$ priming on salt tolerance in sunflower germination and seedling grown under salinity conditions. African. $J$. Biotech., 9: 1764-1770.

Barton, L., Newsome, S.D., Chen, F.H., Wang, H., and Guilderson, T.P. (2009).Agricultural origins and the isotopic identity of domestication in northern China.Proc. Natl. Acad. Sci. U.S.A., 106: 5523-5528.

Bassi, G.S. Sharma, B.S. and Gill. (2011). Pre-sowing seed treatment and quality invigoration in soybean Glycine max (L) Merrill \}. Seed Res., 31: 81-84.

Benabdelmouna, A., Abirached-Darmency, M., and Darmency, H. (2001). Phylogenetic and genomic relationships in Setaria italica and its close relatives based on the molecular diversity and chromosomal organization of $5 \mathrm{~S}$ and $18 \mathrm{~S}-5.8 \mathrm{~S}-25 \mathrm{~S}$ rDNA genes. TheorAppl Genet., 103: 668-677.

Biswas, J.K. (1994). Physiological aspects of seedling establishment of direct seeded rice under simulated lowland condition. Ph.D. Thesis, Central Luzon State Univ, Munoz, Nueva Ecija, Philippines, 186.
Capron, I., Corbineau, F., Dacher, F., Job, C., Come, D. and Job, D. (2000). Sugar beet seed priming: Effects of priming conditions on germination, Solubilization of 11-s globulin and accumulation of LEA proteins. Seed Science and Research., 10: 243-254.

Channappagoudar, B.B., Hiremath, S., Bradar, N.R., Koti, R.V. and Bharamagoudar, T.D. (2008). Influence of MorphoPhysiological and biochemical traits on the productivity of barnyard millet. Karnataka J. Agric. Sci., 20(3):477480 .

Chavoshinasab, S., Sharif Zadeh, F. and Abbasi, A. (2010). The effect of postpriming treatments on seed longevity of Viciada sycrapa and $V$. ervillia primed seeds. The requirements for degree of Master of Science (M. Sc.) in Seed Science and Technology.

Conrath, U., Thulke, O., Katz, V., Schwindling S. and Kohler, A. (2002). Priming as a mechanism in induced systemic resistance of plants.Europ. $J$. Plant Pathol., 107: 113-119.

Copeland, L.O., McDonald, M.B. (2001). Principles of seed science and technology. Kluwer Academic Publishers, Massachusetts, USA.

Cramer, G.R. Epstein, E. and Lauchli, (2011).Effect of sodium, potassium and calcium on salt stressed barley. 1. Growth analysis, Plant Physiology. 80,83-88.

Das, S., Dash, F.M., Nandi, A.K., Senapati, N., Sarkar, S. and Pandey, G. (2014). Seed quality index an estimate used to predict response of bottle gourd seeds (Lagenaria siceraria (Mol.) Standl) to hydro- and osmo-priming. Advances in Applied Agricultural Science Volume 02: 12, 01-10, 2383-4234.

Deb, P., Das, A., Ghosh, S.K. and Suresh, C.P. (2010). Improvement of seed germination and seedling growth of 
papaya (Carica papaya L.) through different pre-sowing seed treatments. ActaHorticulturae., 851: 313-316.

Demir, I., and Oztokar, C. (2003). Effect of salt priming on germination and seedling growth at low temperature in watermelon seed during development. Seed science and technology., 31: 765770.

Desai, S., Reddy, M.S. and Kloepper, J.W. (2002).Comprehensive testing of biological control agents. In S. Gnanamanickam (Ed) Biological control of crop diseases. New York: Marcel Dekker, Inc., pp. 387-420.

Desraj, (2002). Studies on viability and vigour in coriander (Coriandrum sativum L.). M. Sc. Thesis, submitted to Chaudhary Charan Singh Haryana Agricultural University, Hisar.

Devi, P.B., Vijayabharathi, R., Sathyabama, S., Malleshi, N. G. and Priyadarisini, V. B. (2011).Health benefits of finger millet (Eleusine coracana L.) polyphenols and dietary fiber: a review. J. Food Sci. Technology.

Dharmaraj, U., SathyendraRao, B.V., Sakhare, S.D. and Inamdar, A.A. (2016). Preparation of semolina from foxtail millet (Setaria italica) and evaluation of its quality characteristics. J. Cereal Sci., 68, 1-7.

Dhorhan, V.S. and Gudadhe, S.P. (2012).Effect of plant growth regulators on seed germination and seedling vigour in Asparagus sprengeri Regelin. International Research Journal of Biological Sciences, 1, pp. 6-10.

Doust, A.N., Kellogg, E.A., Devos, K. M. and Bentsen, J. L. (2009). Foxtail millet: a sequence-driven grass model system. Plant Physiol., 149: 137-141.

El-Keltawi, N.E. and Croteau, R. (2000). Influence of foliar applied cytokinins on growth and essential oil content of several members of the Lamiaceae, Phytochemistry., 26: 891-895.

FAO, (2009). FAOSTAT. Food and Agriculture Organisation of the United Nations. FAOSTAT. http://faostat.fao. org/site/339/ default.aspx.

Farooq, M., Basra, S.M.A. and Hafeez, K. (2006). Seed invigoration by osmohardening in gram. Seed Sci. Technol., 34: 181-187.

Farooq, M., Wahid, A. and Kadambot, H.M. (2012). Micronutrient application through ed treatments. A review. Journal of Soil Sci Plant Nutri., 12: 125-142.

Feldman, M.J., Paul, R.E., Banan, D., Barrett, J.F. and Sebastian, J. (2017).Time dependent genetic analysis links field and controlled environment phenotypes in the model $\mathrm{C} 4$ grass setaria. PLoS Genet., 13:e1006841.

Finch-Savage, W.E., Dent, K.C. and Clark, L.J. (2004). Soak conditioned and temperature following sowing influence the response of Maize (Zea mays L.) seeds to on -farm priming (Pre sowing seed soak) Silsoe Research Institute, West park, Silsoe. Bedford MK 45. UK.

Fisher, R.A. (1936). The correlation between relative on the supposition of genotypes grown in Kumaun Himalaya, Indian Journal Genetics., 66(1): 37-38.

Galhaut, L., Lespinay, A., Walker, D.J., Bernal, M.P., Correal, E. and Lutts, S. (2014). Seed priming of Trifolium repens L. improved germination and early seedling growth on heavy metalcontaminated soil. Water Air Soil Pollution., 225: 1-15.

Ghassemi-Golezanik, A., Aliloo, A., Valizadeh, M. and Moghaddam, M. (2008). Effects of hydro and osmopriming on seed germination and field emergence of lentil (Lens culinaris 
Medik.). Not. Bot. Hort. Agrobot. Cluj., 36(1):29-33.

Giba, Z., Grubisic, D. and Konjevi, R. (2006). Seeking the Role of NO in Breaking Seed Dormancy. Plant Cell Monographs., 5:91-111.

Golezani, K.G., Jafari, S.F. and Kolvanagh, J.S. (2011).Seed priming and field performance of soybean (Glycine max L.) in response to water limitation. Notulae Botanicae Horti Agrobotanici Cluj-Napoca., 39:186-189.

Goto, F., Yoshihara, T., Shigemoto, N., Toki, S. and Takaiwa, F. (1999).Fortification of rice seed by the soybean ferritin gene. Nat Biotechnol., 17:282-6.

Guan, B., Zhou, D., Zhang, H., Tian, Y., Japhet, W. and Wang, P. (2009).Germination responses of Medicago ruthenica seeds to salinity, alkalinity, and temperature. Journal of Arid Environments., 73:135-138.

Harris, D., Pathan, A.K., Gothkar, P., Joshi, A. Chivasa, W. and Nyamudeza, P. (2005).On -farm seed priming: using participatory methods to revive and refine a key technology, Agricultural Systems., 69(1-2): 151-164.

Harris, D., Rashid, A., Miraj, G., Arif, M. and Shah, H. (2007). On-farm' seed priming with zinc sulphate solutionA cost-effective way to increase the maize yields of resource- poor farmers. Field Crops Research., 102:119-127.

HimaBindu, N., and Sumathi, S., (2003).Organoleptic evaluation and nutrient composition of foxtail millet products. Paper presented at the 5 th International food convention, Mysore, 5-8 December, p. 121.

Hossain, M.A., Arefin, M.K., Khan, B.M. and Rahman, M.A. (2005).Effects of Seed Treatments on Germination and Seedling Growth Attributes of Horitaki (Terminalia chebula Retz.) in the nursery. Research Journal of
Agriculture and Biological Sciences., 1(2): 135- 141.

Huang, P., Jiang, H., Zhu, C., Barry, K., and Jenkins, J. (2017).Sparse panicle is required for inflorescence development in Setariaviridis and maize. Nat. Plants., 3: 17054.

Huang, P., Shyu, C., Coelho, C.P., Cao, Y. and Brutnell, T.P. (2016). Setaria viridis as a model system to advance millet genetics and genomics. Front. Plant Sci.,7:1781.

ISTA (International Seed Testing Association). (1924). International Rules for Seed Testing. Seed Sci. and Tech. 4: 3-49.

ISTA, (1999). International rules for seed testing. Seed Sci., \& Technol., Supplement Rules: 27-57.

Jaleel, C.A., Manivannan, P., Sankar, B., Kishorekumar, A., Gopi, R. (2007). Water deficit stress mitigation by calcium chloride in Catharanthus roseus: Effects on oxidative stress, proline metabolism and indole alkaloid accumulation. Colloids Surf B., 60: 110-116.

Jendrzejczak, E. and Smigerska, K. (2014). Impact of pre-sowing soaking of amaranth seeds in solutions of growth regulators part ii. Effect of treatments processing seed material on growth, development and yield of amaranth cv. Rawa L. ActaScientiarum Polonorum Agricultura., 13(4):53-64.

Kaur, H., Chawla, N., Bassi, G., Pathak, M. (2015). Effect of different seed priming treatments on germination of Okra (Abelmoschus esculentus L.). International Journal of Current Science., 15:51-58.

Kokila, M. (2014).Physiological, biochemical, molecular and histological basis of seed biopriming with biocontrol agent and liquid biofertilizers in rice hybrid CORH 4 and its parental lines. Ph.D 
(Ag.) Thesis, Tamil Nadu Agricultural University, Coimbatore.

Koomeef, M., Bentsink, L. and Hilorst, H. (2002).Seed dormancy and germination.

Current Opinion of Plant Biology., 5: 33-36.

Korkmaz, A. (2005). Inclusion of Acetyl Salicylic Acid and Methyl Jasmonate into the Priming Solution Improves Low-temperature Germination and Emergence of Sweet Pepper. Hort Science., 40(1): 197-200.

Kumar, V. (2010). Studies on seed viability and vigour in naturally aged seeds of coriander (Coriandrum sativum L.). M. Sc. Thesis submitted to Chaudhary Charan Singh Haryana Agricultural University, Hisar.

Kumar, V.A. and Sundareswaran, S. (2011). Effect of foliar application of chemicals and growth regulators on growth and seed yield in coriander (Coriandrum sativum L.). Prog. Hort.,43:193-195.

Kunal, V., Jadhav, Kayande, N.V. and Wandhare, M.R. (2012).Effect of seed priming on yield and yield components of soybean Int. J. Plant Sci., 6(4): 587595.

Kurdikeri, M.B., Ashwataiah, B. and Rajendra Prasad, S. (2003). Seed quality of invigourated seeds of maize hybrid.Mysore J Agril. Sci., 27: 237242.

Lata, C., Gupta, S., and Prasad, M. (2013).Foxtail millet: a model crop for genetic and genomic studies in bioenergy grasses. Crit. Rev. Biotechnol., 33, 328-343.

Lata, C., Jha, S., Dixit, V., Sreenivasulu, N. and Prasad, M. (2011).Differential antioxidative responses to dehydrationinduced oxidative stress in core set of foxtail millet cultivars [Setaria italica(L.)]. Protoplasma248, 817828.
Maasoumeh Asadi Aghbolaghi and Mohannadsedghi. (2014). The effect of osmo and hormone priming on germination and seed reserve utilization of millet seeds under drought stress. Journal of stress physiology \& biochemistry., 10 (1):,214-221.

Mahmoudi, H., Massoud, R.B., Baatour, O., Tarchoune, I., Salah, I.B., Nasri, N., Abidi, W., Kaddour, R., Hannoufa, A., Lachaal, M. and Ouerghi, Z. (2012).Influence of different seed priming methods for improving salt stress tolerance in lettuce plants. Journal of Plant Nutrition 35: 19101922.

Milosevic, M.M., Vujakovic, D. and Karagic, (2010). Vigour tests as indicators of seed viability. Genetika., 42(1): 103118.

Moghadam, A.K. and Mohammadi, K. (2013).Different priming treatments affected germination traits of safflower. App Sci Rep., 2, 22-25.

Murungu, F.S., Chiduza, E., Nyamugafata, P., Clark, L.J., Whalley, W.R. and FinchSavage, W.E. (2004).Effects _on-farm seed priming' on consecutive daily sowing occasions on the emergence and growth of maize in semi-arid Zimbabwe, Fields Crops Research., 89(1): 49-57.

Muthamilarasan, M. Dhaka, A. Yadav, R. Prasad, M. (2016).Exploration of millet models for developing nutrient rich graminaceous crops. Plant Sci., 242, 89-97.

Nader Chaparzadesh, Minaish Ghodrati Chagharlou, (2008). Alleviation of adverse effect of metal on Allium cepa L. by exogenous Ascorbic acid Application Journal of Plant Physiology and Breeding., 2014; 3(2):5168.

Nascimento, W. and West, S.H. (2000). Dry 
of primed seed and its effect on seed germination and deterioration. Seed Science and Technology., 28: 211-215.

Nautiyal, N. and Shukla, K. (2013). Evaluation of seed priming zinc treatments in chickpea for seeding establishment under zinc deficient condition. Journal of Plant Nutrition.,36: 251- 258.

Pallavi, M., Sudheerkumar, S., Dangi, K.S. and Reddy, A.V. (2003). Effect of seed aging on physiological, Biochemical ad yield attributes in sunflower (Helianthus annuus L.) cv. Modem. Seed Research., 3: 161 - 168.

Panse, V.G. and Sukhatme, P.V. (1967). Statistical Methods for Agricultural Workers. Indian Council of Agricultural Research: 103-108.

Pant, S.R., Irigoyen, S., Doust, A.N., Scholthof, K.B. and Mandadi, K.K. (2016). Setaria: a food crop and translational research model for $\mathrm{c} 4$ grasses. Front. Plant Sci., 7:1885.

Piri, M., Mahdieh, M.B., Olfati, J.A. and Peyvast, G. (2009).Germination and seedling development of cucumber are enhanced by priming at low temperature. International Journal of Vegetable Science., 15(3):285-292.

Prabhu, T. and Kumar, P. S. (2018).Seed hardening with organics and inorganics on seedling, growth and yield characters in rice cv. ADT 37. Plant Arch., 18(1): 693-696.

Prajapati, K.R., Patel, D.B., Patil, K. and Bhadane, R. S. (2017).Effect of seed hardening on morpho-physiological and yield parameters in black gram (Vigna mungo L.).Int. J. Chem. Stud., 5(4): 439-441.

Prasad, T.N.V.K.V., Sudhakar, P., Sreenivasulu, Y., Latha, P., Munaswam, Y. and Raja reddy, K. (2012). Effect of nano scale zincoxide particles on the germination, growth and yield of peanut. Journal of PlantNutrition., 35(6): 905- 927.

Rahman, I.U., Ali, N., Rab, A. and Shah, Z. (2013). Role of pre storage seed priming in controlling seed deterioration during storage. Sarhad J. Agric., 29: 379-386.

Raj, N.S., Shetty N.P. and Shetty, H.S. (2004). Seed biopriming with Pseudomonas fluorescens isolates enhances growth of pearl millet plants and induces resistance against downy mildew. Intl. J. Pest Mgt., 50(1): 41- 48.

Rajpar, I., Khanif, Y.M. and Memon, A.A. (2015).Effect of Seed Priming on Growth and Yield of Wheat (Triticum aestivum L.) Under Non-Saline Conditions. Inter J Agri Res., 1: 25964.

Ramamoorthy, K., Natarajan, N. and Lakshmanan, A. (2000).Seed biofortification with Azospirillum spp. For improvement of seedling vigour and productivity in rice (Oryza sativa L.).Seed sci. \& technol., 28: 809-815.

Rashid, A., Hallington, P.A, Harris, D. and Khan, P. (2006).On-farm seed priming for barley on normal, saline, salinesodic soils in Northwest Frontier Province, Pakistan. European J. Agron., 24: 276-281.

RashmiYadav and Vijay Kumar Yadav. (2011). Barnyard millet: Amazing crop for nutritional security in Himalayan region. Indian Farming.,61(4):6-9.

Ravindran, G. (1991). Studies on millets: Proximate composition, mineral composition, and phytate and oxalate contents. Food Chem., 39(1): 99-107.

Rawat, L., Singh, Y., Shukla, N., Kumar, J. (2011). Alleviation of the adverse effect of salinity stress in wheat (Triticum aestivum L.) by seed biopriming with salinity tolerant isolates of Trichoderma harzianum. $J$ Pl. soil., 34(1): 387-400. 
Rinku, V., Patel, Krishna, Y., Pandya, R.T., Jasrai, and NayanaBrahmbhatt.(2017). Effect of hydropriming and biopriming on seed germination of brinjal and tomato seed. Research journal of agriculture and forestry sciences., 5(6): 1-14.

Robert Ronzio. (2004). Theencyclopedia of nutrition and good health, 2nd edition, viva books Pvt Ltd, New Delhi.

Saleh, A.S.M., Zhang, Q., Chen, J. \& Shen, Q. (2013).Comprehensive Reviews in Food Science and Food Safety., 12, 281-295.

Sandyarani, G.M. (2002). Influence of seed treatment with chemicals and botanical on storability and field performance of fresh and aged hybrid cotton seeds. M.Sc. (Agri.) Thesis. Univ. Agric. Sci, Dharwad.

Sarika, G., Basavaraju, G.V., Bhanuprakash, K., Chaanakeshava, V., Paramesh, R. and Radha, B.N. (2013). Investigation on seed viability and vigour of aged seed by priming in French bean. Vegetable Science., 40: 169-173.

Sedghi, M., Nemati, A. and Esmaielpour, B. (2010). Effect of seed priming on germination and seedling growth of two medicinal plants under salinity. Emirates Journal of Food and Agriculture., 22 (2): 130-139.

Sharma, A.D., Rathore, S.V.S., Srinivasan, K. and Tyagi, R.K. (2014).Comparison of various seed priming methods for seed germination, seedling vigour and fruit yield in okra (Abelmoschus esculentus L. Moench). Sci. Hortic., 165: 75-81.

Sivakalai, R. and Krishnaveni, K. (2017). Effect of bio-priming on seed yield and quality in pumpkin cv $\mathrm{CO} 2$. International journal of current microbiology and applied science., 6(12): 85-90.

Sivasankaridevi, T., Shivaprakash, M.K. and Maina, C.C. (2013). Efficacy of seed bio- priming enhancing vigour of cucumber (Cucumis sativus L.) under biotic stress conditions. Mysore. $J$ Agric. Sci., 47(1): 107-111.

Soubhagya Behera, (2016). A study on the effect of hormonal priming (GA3) on seed quality parameters of solanaceous vegetables. International Journal of Agricultural Science and Research., 6(30):337-348.

Sridevi, R. and Manonmani, V. (2016). Seed priming effect on physiological traits of kodo millet and barnyard millet. Int J. Agric. Sci. Res., 6(2): 759-772.

Srivastava, A.K. and Bose, B. (2012).Effect of nitrate seed priming on phenology, growth rate and yield attributes in rice (Oryza sativa L.). Vegetos., 25: 174181.

Srivastava, J.P., Yadav, R.D.S., Kushwaha, A.P.G.D. (2011). Seed priming: ecofriendly approach for seed enhancement vis-a-vis nursery management. Crop Research., 42: 223226.

Talebian, M.A., Sharifzadeh, F., Jahansouz, M.R., Ahmadi, A. and Naghavi, M.R. (2008). Evaluation the effect of seed priming on germination, seedling stand and grain yield of wheat cultivars (Triticum aestivum L.) in three different regions in Iran. Iranian $J$ Crop Sc. 39(1): 145-154.

Tiwari, D.K., Pandey, P., Giri, S.P. and Dwivedi, J.L. (2011).Effect of $\mathrm{GA}_{3}$ and other plant growth regulators on hybrid rice seed production. Asian J. Plant Sci., 10:133-139.

Vasudeva, S. Vishwanathan, K.H. Aswathanarayana, K.N. and Swamy, Y.M.I. (2010). Hydration behaviour of food grains and modelling their moisture pick up as per Peleg's equation: Part I. Cereals. J. Food Sci. Technol. 47, 34-41.

Vazirimehr, M.R., Ganjali, H.R., Rigi, K. and 
Keshtehgar, A. (2014).Effect of seed priming on quantitative traits corn. International Journal of Plant Science., 4: 134-140.

Veena, S., Chimmad, B., Naik, V., R. K. and Shanthakumar, G. (2005). Physicochemical and nutritional studies in barnyard millet. Karnataka J. Agric. Sci., 18 (1): 101-105.

Venkatesh Babu, S.D., BalajiNayak and Sujathamma, P. (2018). Studies on seed priming on seedling vigour, crop growth and yield of groundnut (Arachis hypogaea L.) under rainfed conditions. Int. J. Pure App. Biosci., 6(5): 238-242.

Wang, H., Miyazaki, S., Kawai, K., Deyholos, M., Glabraith, D.W. and Bohnert, H.J. (2003). Temporal progression of gene expression responses to salt shock in maize roots. Plant Mol Biol., 52: 873891.

Xu, W., Wei, L., Qu, W., Liang, Z. and Wang, J. (2011).A novel antifungal peptide from foxtail millet seeds. J. Sci. Food Agric. 91., 1630-1637.

Yadava, H.S. and Jain, A.K. (2006). Advances in Kodomillet Research (Indian Council of Agri. Research), India.

Yang, J., Thames, S., Best, N.B., Jiang, H. and Huang, P. (2018). Brassinosteroids modulate meristem fate and differentiation of unique inflorescence morphology in Setaria viridis. Plant Cell., 30, 48-66.

Yang, L., Cui, X.T. and Shen, H.L. (2009).Effects of plant growth substances and temperature on seed germination of Sorbuspohuashanensi (Hance) Hedl. Plant Physiology Communications., 45: 555-560.

Yari, L., Aghaalikani, M. and Khazaei, F. (2010). Effect of seed priming duration and temperature on seed germination behaviour of bread wheat (Triticum aestivum L.). ARPN Journal of Agricultural and Biological Science., $5: 1$.

\section{How to cite this article:}

Rajaka Karthik Kumar, Arun kumar Chaurasia, Nuthalapati Karthik and Kavitha, M. 2021. Effect of different Pre-sowing Seed Treatments for Improving Growth, Yield and Yield Attributes in Foxtail Millet (Setaria italica (L.) P. Beauv). Int.J.Curr.Microbiol.App.Sci. 10(02): 1791-1804. doi: https://doi.org/10.20546/ijcmas.2021.1002.212 